A comparison of the rates of native and foreign-born admissions to public mental hospitals in Ohio during a $41 / 2-y e a r$ period tends to support earlier findings that migration rather than foreign birth per $s e$ is significant in the comparative incidence of mental disease.

\title{
Immigration and Insanity
}

\author{
BEN Z. LOCKE, M.S., MORTON KRAMER, Sc.D., \\ and BENJAMIN PASAMANICK, M.D.
}

$I^{1}$ NFORMA'TION on mental illness among the foreign-born is sparse and very little is current. Indeed, in a recently published book the data in the section on nativity pertained to the period 1917-34 (1). Also, aside from gross national data derived from the decennial census of institutions, most of the detailed available information on this subject concerns admissions to mental hospitals in but three States: Minnesota (2), Massachusetts (3), and New York $\left({ }^{\prime}-6\right)$.

This paper reviews these early data and presents the rates at which native and foreignborn were admitted to Ohio public mental hospitals during the period 1948 to June 30, 1952.

\section{Historical Review}

In the introductory remarks of the 1880 census ( $r)$ it was stated that "The extraordinary ratio of insanity among the foreignborn has attracted wide attention." However, this report pointed out that "the question of age has a bearing upon the comparative num-

Mr. Locke serves as chief of the Consultation Section, Biometrics Branch, National Institute of Mental Health, Public Health Service. Dr. Kramer is chief of the Biometrics Branch, and Dr. Pasamanick is director of research of the Columbus Psychiatric Institute and Hospital, College of Medicine, Ohio State University. ber of the insane who are of native and of foreign birth" and that "the difference disappears, in large measure, when, instead of comparing the number of insane with the total population, we compare it with the population above the age at which insanity ordinarily occurs, that is to say above the age of 15 years. I have here put the margin very low." As a result of this simple but incomplete correction for age it was shown that "instead of the foreign insane being $21 / 2$ times as numerous, in proportion, as the native white insane, they are about 50 percent more numerous."

The 1910 census (8) also pointed out that while "the foreign-born have an unduly large representation in insane asylums" the ratios "if regarded as an index of the tendency to insanity among immigrants as compared to the native population are misleading." It then states that "the age difference probably goes further than any other factior toward explaining the contrast between the native white and the foreign-born white in respect to the proportionate numbers admitted to hospitals for the insane." Other factors it mentions as relevant are sex ratios, geographic distribution, and the degree of concentration in cities besides the migration factor and the concomitant consequence of a changed environment involving "new physical, economic, and social conditions."

However, in analyzing mental disease admission rates in Minnesota for the four decades 
from 1889 through 1929, Ødegaard reported that the standardized first admission rates among the Norwegian born were significantly higher statistically than the rates for the nativeborn (2). In his analysis, Ødegaard stressed the importance of initial selection and the problems of assimilation, but for each decade analyzed the difference in the standardized admission rates between the two groups decreased.

In presenting his findings regarding nativity and mental disease in Massachusetts, 1917-33,
Dayton also stated that "Early reports on the relative incidence of mental disorder in the foreign-born and in the native-born favored the native-born in a very decided manner. Later it was discovered that the greater part of the observed differences between the two nativity groups was statistical rather than actual ..."(3).

The Massachusetts data, in which age was fully considered, showed the foreign-born to have higher first admission rates than the native-born. But as Dayton pointed out, the

Table 1. First admission rates per 100,000 to Ohio public mental hospitals of white persons, by age, sex, nativity, and residence, all diagnoses, 1948 to June 30,1952

\begin{tabular}{|c|c|c|c|c|c|c|c|c|}
\hline \multirow{4}{*}{ Age (in years) } & \multicolumn{8}{|c|}{ White male } \\
\hline & \multicolumn{4}{|c|}{ Metropolitan } & \multicolumn{4}{|c|}{ Nonmetropolitan } \\
\hline & \multicolumn{2}{|c|}{ Native-born } & \multicolumn{2}{|c|}{ Foreign-born } & \multicolumn{2}{|c|}{ Native-born } & \multicolumn{2}{|c|}{ Foreign-born } \\
\hline & $\underset{\text { ber }}{\text { Num- }}$ & Rate & $\begin{array}{l}\text { Num- } \\
\text { ber }\end{array}$ & Rate & $\underset{\text { ber }}{\text { Num- }}$ & Rate & $\underset{\text { ber }}{\text { Num- }}$ & Rate \\
\hline $\begin{array}{l}\text { Crude total } \\
\text { Adjusted total } 1\end{array}$ & 7,357 & $\begin{array}{l}95.5 \\
98.2\end{array}$ & 1,352 & $\begin{array}{l}\text { 151. } 9 \\
119.4\end{array}$ & 4,015 & $\begin{array}{l}91.4 \\
90.8\end{array}$ & 189 & $\begin{array}{l}\text { 159. } 5 \\
114.1\end{array}$ \\
\hline $\begin{array}{l}10-19 \\
20-29 \\
30-39 \\
40-49 \\
50-59 \\
60\end{array}$ & $\begin{array}{r}360 \\
1,368 \\
1,481 \\
1,428 \\
980 \\
782 \\
958\end{array}$ & $\begin{array}{r}27.1 \\
83.2 \\
92.8 \\
113.7 \\
103.8 \\
133.2 \\
276.3\end{array}$ & $\begin{array}{r}6 \\
28 \\
79 \\
136 \\
296 \\
430 \\
377\end{array}$ & $\begin{array}{r}62.9 \\
98.7 \\
142.5 \\
92.5 \\
111.1 \\
166.1 \\
\text { 303. } 7\end{array}$ & $\begin{array}{l}185 \\
597 \\
709 \\
772 \\
589 \\
502 \\
661\end{array}$ & $\begin{array}{r}\text { 20. } 9 \\
74.3 \\
93.1 \\
120.3 \\
110.6 \\
117.8 \\
192.3\end{array}$ & $\begin{array}{r}4 \\
13 \\
22 \\
37 \\
45 \\
68\end{array}$ & $\begin{array}{r}88.6 \\
166.6 \\
124.5 \\
132.4 \\
131.4 \\
279.6\end{array}$ \\
\hline \multirow{4}{*}{ Age (in years) } & \multicolumn{8}{|c|}{ White female } \\
\hline & \multicolumn{4}{|c|}{ Metropolitan } & \multicolumn{4}{|c|}{ Nonmetropolitan } \\
\hline & \multicolumn{2}{|c|}{ Native-born } & \multicolumn{2}{|c|}{ Foreign-born } & \multicolumn{2}{|c|}{ Native-born } & \multicolumn{2}{|c|}{ Foreign-born } \\
\hline & $\begin{array}{c}\text { Num- } \\
\text { ber }\end{array}$ & Rate & $\underset{\text { ber }}{\text { Num- }}$ & Rate & $\underset{\text { ber }}{\text { Num- }}$ & Rate & $\underset{\text { ber }}{\text { Num- }}$ & Rate \\
\hline $\begin{array}{l}\text { Crude total } \\
\text { Adjusted total } 1\end{array}$ & 6,469 & $\begin{array}{l}\text { 77. } 9 \\
77.6\end{array}$ & $\begin{array}{c}1,035 \\
-\end{array}$ & $\begin{array}{l}124.7 \\
111.3\end{array}$ & 2,879 & $\begin{array}{l}63.1 \\
62.9\end{array}$ & 116 & $\begin{array}{r}\text { 106. } 9 \\
98.4\end{array}$ \\
\hline 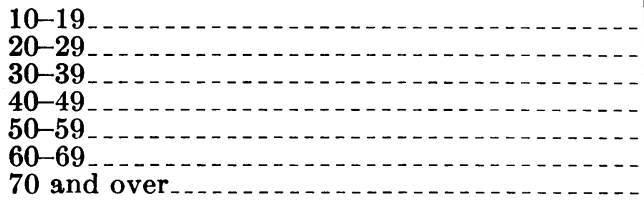 & $\begin{array}{r}249 \\
1,178 \\
1,472 \\
1,110 \\
855 \\
662 \\
943\end{array}$ & $\begin{array}{r}\text { 18. } 4 \\
64.8 \\
\text { 86. } 8 \\
\text { 84. } 7 \\
\text { 86. } 0 \\
\text { 98. } 7 \\
\text { 202. } 0\end{array}$ & $\begin{array}{r}7 \\
31 \\
97 \\
159 \\
240 \\
208 \\
293\end{array}$ & $\begin{array}{r}\text { 84. } 3 \\
68.5 \\
157.4 \\
104.9 \\
104.7 \\
99.6 \\
234.2\end{array}$ & $\begin{array}{l}110 \\
486 \\
624 \\
525 \\
388 \\
347 \\
399\end{array}$ & $\begin{array}{r}\text { 12. } 7 \\
57.9 \\
79.0 \\
79.9 \\
69.3 \\
75.6 \\
101.2\end{array}$ & $\begin{array}{r}2 \\
6 \\
10 \\
19 \\
20 \\
24 \\
35\end{array}$ & $\begin{array}{r}103.4 \\
59.7 \\
110.4 \\
120.1 \\
77.7 \\
97.7 \\
163.6\end{array}$ \\
\hline
\end{tabular}

${ }^{1}$ Age-adjusted rates based on total native-born Ohio population.

NoTE: The numbers of admissions are for the entire $4 \frac{1}{2}$-year period; the rates are on an average annual basis. 
Figure 1. Average annual first admission rates to Ohio State public mental hospitals, for white males, by age, nativity, and residence, all diagnoses, 1948 to June 30, 1952

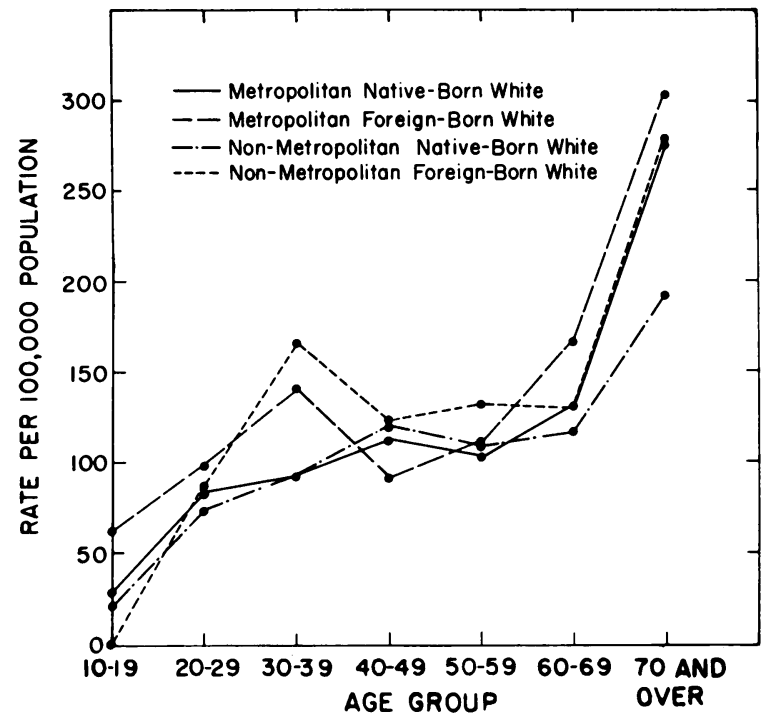

native-born had certain protections which might have tended to keep him out of the hospital. The foreign-born was not only handicapped by the absence of these protective mechanisms (familial, social, and economic) but had language difficulty as well. Another factor, although a minor one, was the greater use of private facilities by the native-born.

Malzberg, in his study of first admissions to all institutions for mental disease in New York State, 1929-31, found "that even after age differences had been eliminated, the foreign-born still had a higher rate of first admissions than the native-born, though the excess was much less than that derived solely on the basis of crude rates" (4). However, after reviewing the data from several aspects he comes to the general conclusion that the available data indicate few, if any, differences in the relative incidence of mental disease among native and foreign whites in New York State that cannot be accounted for adequately on the basis of environmental and age differentials.

In a similar study involving 1939-41 data, Malzberg and Lee minimized the importance of the overall differential of 11 percent among males. They took the 21 percent difference in age standardized rates for total psychoses in
Figure 2. Average annual first admission rates to Ohio State public mental hospitals, for white females, by age, nativity, and residence, all diagnoses, 1948 to June 30, 1952

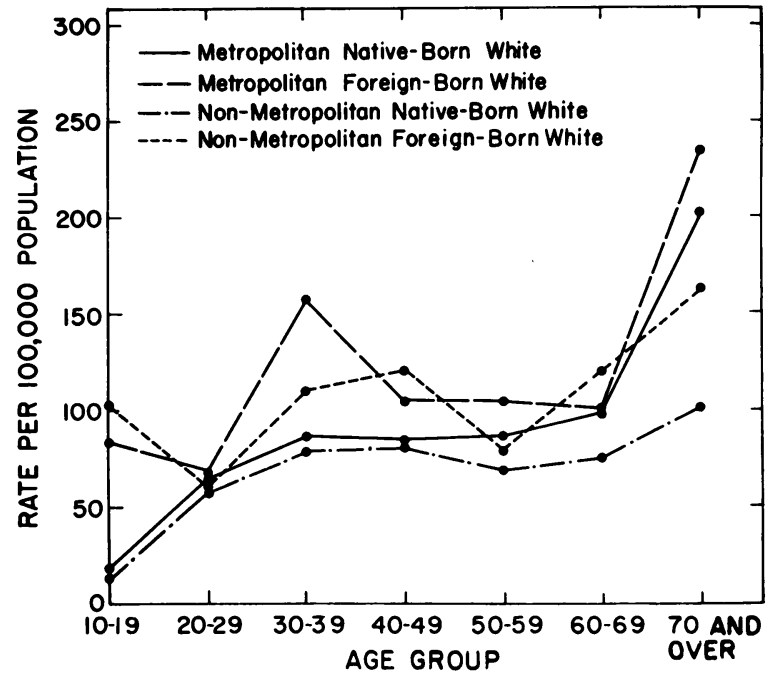

females as evidence of an important difference in the patterns of first admissions by nativity of white females (5).

Based on the 1939-41 data, Malzberg stated that a population native to a given environment has lower rates of mental disease than the population in the same environment which is of foreign birth $(6)$. This conclusion was qualified by the statement that the more we compare the two populations on a comparable basis, the greater is the approximation in rates of first admissions.

\section{Ohio State Study Results}

According to the 1950 census, 5.6 percent of Ohio's population was foreign-born, and 19 States had larger percentages (9). New York had the highest percentage foreign-born, 16.8; Massachusetts had 15.2 percent; and Minnesota 7.0 percent. In Ohio, the 1950 foreign-born white population numbered slightly over 440,000 .

During 1948 to June 30, 1952, there were 2,692 foreign-born white first admissions to the Ohio public mental hospitals (aged 10 and over). In the same period, 20,720 native-born whites were admitted. As shown in table 1, the crude rates for the foreign-born are much 
higher than those for the native-born. Age, the same factor to which attention was called in the 1880 census, appears to account for part of the disparity in these crude rates. In Ohio, for example, the median age of the foreignborn and native-born whites, was, respectively, 42 and 19 in 1880, 39 and 24 in 1910, and 57 and 30 in 1950. Nevertheless, when the 1950 rates were adjusted for age, the rates remained higher for the foreign-born, as would be expected since figures 1 and 2 and table 1 show that for most age groups the rates were either at the same level or higher for the foreign-born.

In the New York State study, the differential in rates between the foreign-born and the native-born females was such that Malzberg and Lee stated: "The poorer showing of all foreignborn females relative to natives tends to substantiate Ødegaard's hypothesis that females make less satisfactory adjustments to migration than do males, or alternatively that female immigrants are not as well 'selected' as are male

Table 2. Number of admissions and first admission rates per 100,000 to Ohio public mental hospitals for native-born, by age, sex, color, and place of birth, all diagnoses, 1948 to June 30, 1952

\begin{tabular}{|c|c|c|c|c|c|c|c|c|}
\hline \multirow{4}{*}{ Age (in years) } & \multicolumn{8}{|c|}{ Native-born males } \\
\hline & \multicolumn{4}{|c|}{ White } & \multicolumn{4}{|c|}{ Nonwhite } \\
\hline & \multicolumn{2}{|c|}{ Ohio } & \multicolumn{2}{|c|}{ Other States } & \multicolumn{2}{|c|}{ Ohio } & \multicolumn{2}{|c|}{ Other States } \\
\hline & $\begin{array}{l}\text { Num- } \\
\text { ber }\end{array}$ & Rate & $\begin{array}{l}\text { Num- } \\
\text { ber }\end{array}$ & Rate & $\underset{\text { ber }}{\text { Num- }}$ & Rate & $\underset{\text { ber }}{\text { Num- }}$ & Rate \\
\hline $\begin{array}{l}\text { Crude total } \\
\text { Adjusted totali }\end{array}$ & 8,153 & $\begin{array}{l}90.4 \\
93.3\end{array}$ & 3,220 & $\begin{array}{l}109.9 \\
103.7\end{array}$ & 403 & $\begin{array}{l}\text { 151. } 8 \\
178.0\end{array}$ & 1,371 & $\begin{array}{l}221.0 \\
218.3\end{array}$ \\
\hline $\begin{array}{l}\text { 10-19. } \\
20-29 \\
30-39 \\
40-49 \\
50-599 \\
60-69 \\
70 \text { and over }\end{array}$ & $\begin{array}{r}460 \\
1,475 \\
1,538 \\
1,469 \\
1,058 \\
921 \\
1,232\end{array}$ & $\begin{array}{r}\text { 24. } 2 \\
\text { 79. } 0 \\
91.9 \\
114.0 \\
103.5 \\
124.0 \\
232.7\end{array}$ & $\begin{array}{r}86 \\
490 \\
652 \\
732 \\
510 \\
363 \\
387\end{array}$ & $\begin{array}{r}\text { 30. } 4 \\
\text { 88. } 7 \\
99.2 \\
\text { 124. } 4 \\
116.2 \\
141.0 \\
\text { 255. } 3\end{array}$ & $\begin{array}{r}65 \\
165 \\
61 \\
41 \\
28 \\
25 \\
18\end{array}$ & \begin{tabular}{r|}
65.3 \\
220.4 \\
195.3 \\
186.3 \\
130.7 \\
242.6 \\
292.0
\end{tabular} & $\begin{array}{r}41 \\
241 \\
323 \\
274 \\
198 \\
175 \\
119\end{array}$ & $\begin{array}{r}\text { 75. } 3 \\
\text { 206. } 0 \\
214.2 \\
204.9 \\
212.8 \\
\text { 352. } 1 \\
\text { 553. } 2\end{array}$ \\
\hline \multirow{4}{*}{ Age (in years) } & \multicolumn{8}{|c|}{ Native-born females } \\
\hline & \multicolumn{4}{|c|}{ White } & \multicolumn{4}{|c|}{ Nonwhite } \\
\hline & \multicolumn{2}{|c|}{ Ohio } & \multicolumn{2}{|c|}{ Other States } & \multicolumn{2}{|c|}{ Ohio } & \multicolumn{2}{|c|}{ Other States } \\
\hline & $\underset{\text { ber }}{\text { Num- }}$ & Rate & $\underset{\text { ber }}{\text { Num- }}$ & Rate & Num- & Rate & Num- & Rate \\
\hline $\begin{array}{l}\text { Crude total } \\
\text { Adjusted total } 1 \ldots\end{array}$ & 6,702 & $\begin{array}{l}69.8 \\
70.5\end{array}$ & 2,645 & $\begin{array}{l}83.8 \\
78.2\end{array}$ & $\begin{array}{r}297 \\
----\end{array}$ & $\begin{array}{l}105.0 \\
124.0\end{array}$ & 1,023 & $\begin{array}{l}158.0 \\
155.8\end{array}$ \\
\hline 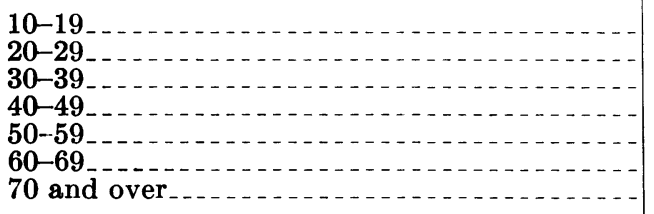 & $\begin{array}{r}305 \\
1,242 \\
1,478 \\
1,091 \\
866 \\
746 \\
974\end{array}$ & $\begin{array}{r}\text { 16. } 1 \\
62.8 \\
84.0 \\
\text { 80. } 7 \\
77.8 \\
\text { 88. } 3 \\
147.3\end{array}$ & $\begin{array}{r}56 \\
420 \\
619 \\
543 \\
375 \\
264 \\
368\end{array}$ & $\begin{array}{r}\text { 18. } 7 \\
63.8 \\
\text { 87. } 7 \\
\text { 90. } 6 \\
\text { 87. } 4 \\
96.3 \\
\text { 195. } 6\end{array}$ & \begin{tabular}{r|}
56 \\
104 \\
53 \\
33 \\
15 \\
15 \\
21
\end{tabular} & $\begin{array}{r}53.5 \\
126.4 \\
144.1 \\
142.3 \\
92.7 \\
125.3 \\
272.1\end{array}$ & $\begin{array}{r}37 \\
199 \\
249 \\
203 \\
158 \\
91 \\
86\end{array}$ & $\begin{array}{r}58.5 \\
142.5 \\
156.6 \\
154.7 \\
186.4 \\
196.6 \\
370.4\end{array}$ \\
\hline
\end{tabular}

1 Age-adjusted rates based on total native-born Ohio population.

Note: The numbers of admissions are for the entire $4 \frac{1}{2}$-year period; the rates are on an average annual basis. 
Figure 3. Average annual first admission rates to Ohio public mental hospitals for nativeborn males, by age, color, and place of birth, all diagnoses, 1948 to June 30, 1952

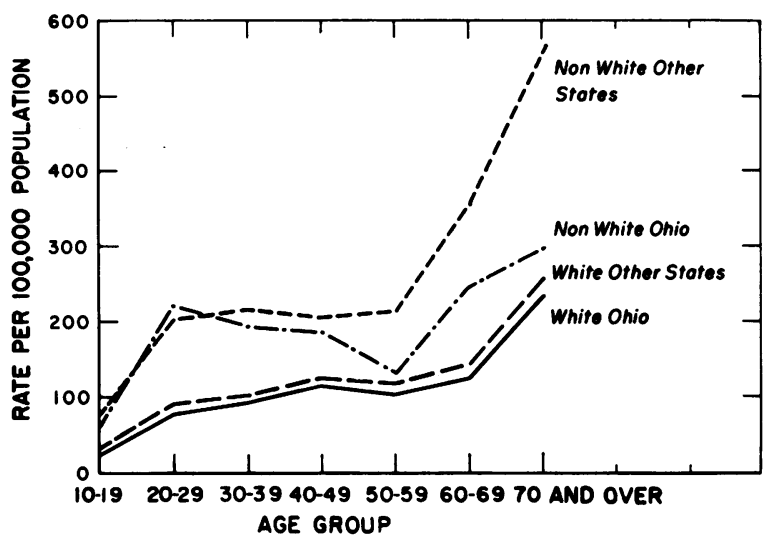

immigrants" (5). The Ohio data substantially agree with the findings of $\emptyset$ degaard and Malzberg.

However, had the rates of first admission for foreign-born and native-born been alike after age adjustment, it would not have been an indication that there are no true differences in their respective incidence of mental illness. It had been mentioned earlier that there were forces, such as lack of family and language, and economic and other problems of assimilation, that might have tended to increase the rate of hospitalization among the foreign-born.

It is also conceivable that cultural differences might have tended to keep some of the foreignborn out of hospitals unless very ill. Also, screening of immigrants and deportation of others may have been more diligently carried out since the 1930's. The proof of not becoming public charges may have raised their level of socioeconomic and educational status somewhat.

Nevertheless, given the current volume of immigration, the factor foreign-born per se does not seem to warrant much attention. What should command considerable concern is the factor of migration. White and nonwhite máles and females born in Ohio had lower rates than their counterparts who were born elsewhere in the United States and subsequently migrated to Ohio (table 2 and figs. 3 and 4). Malzberg and Lee in analyzing the New York State data also found that the rates for native
Figure 4. Average annual first admission rates to Ohio public mental hospitals for nativeborn females, by age, color, and place of birth, all diagnoses, 1948 to June 30, 1952

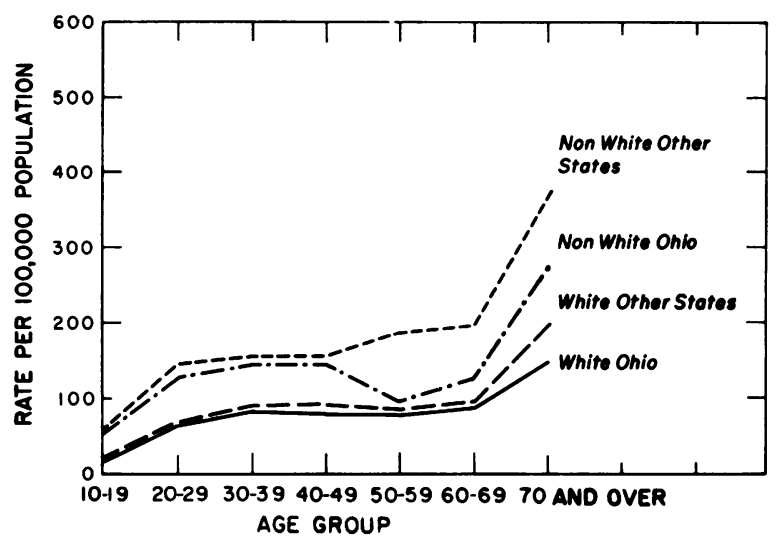

migrants, regardless of color or sex, are strikingly higher than those for persons born in the State (5). Despite the agreement of these two studies, replication for other areas as well as other periods of time is needed. Furthermore, as Dorothy S. Thomas stated in her introduction to "Migration and Mental Disease," such studies must be extended to include analyses of differentials between migrants and nonmigrants in areas of origin as well as in areas of destination (5).

Advantage should be taken of the 1960 census. Information regarding migrants (nativeborn and foreign-born) by such factors as household composition, marital status, education; and occupation could be obtained for mental patients and correlated wth information obtained at the time of the 1960 census. In addition, the psychiatric diagnosis of the patients should be considered in the analysis. Such studies require large numbers of patients. It might be that several States would have to collect, in a comparable fashion, data which could be pooled and analyzed to provide this needed information about mental illness among migrants, both native- and foreign-born.

\section{REFERENCES}

(1) Rose, A. M., Editor: Mental health and mental disorder. New York, W. W. Norton \& Co., 1955, 626 pp.

(2) Ødegaard, D.: Emigration and insanity. Acta psychiat. et neurol. Supp. 4, 1932, 206 pp. 
(3) Dayton, N. A.: New facts on mental disorders. Springfield, Ill., C. C. Thomas, 1940, 486 pp.

(4) Malzberg, B.: Social and biological aspects of mental disease. New York, Utica State Hospital Press, 1940, 360 pp.

(5) Malzberg, B., and Lee, E. S. : Migration and mental disease. New York Social Science Research Council, 1956, 142 pp.

(6) Malzberg, B.: Statistical data for the study of mental disease in New York State, 1939-1941. New York State Department of Mental Hygiene. Albany; New York, 1955, 280 pp.
(7) U.S. Census Office : Report on defective, dependent and delinquent classes. Tenth census, 1880. Washington, D.C., U.S. Government Printing Office, 1888, 581 pp.

(8) U.S. Bureau of the Census: Insane and feebleminded in institutions, 1910. Washington, D.C., U.S. Government Printing Office, 1914, 217 pp.

(9) U.S. Bureau of the Census : Census of the population: 1950. Vol. 2, pt. 35, Ohio. Washington, D.C., U.S. Government Printing Office, 1952, 520 pp.

\section{Community Cancer Demonstration Project Grants}

For the current fiscal year, Congress has appropriated $\$ 1,500,000$ for community cancer demonstration project grants. The Cancer Control Branch, within the Division of Special Health Services, Public Health Service, is administering the fund and is receiving applications from health agencies and nonprofit organizations and institutions. Additional projects may be approved during spring and summer of 1960.

Among types of projects believed to offer the best opportunities for demonstrating better ways of providing community cancer control services are:

- Professional and technical education in cytology.

- Screening female beneficiaries of medical care for cancer of the cervix.

- Selected educational projects, particularly public information and followup services, to emphasize the importance of periodic uterine cytology examinations.

- Professional educational activities emphasizing the importance of including cancer diagnostic aids in complete health examinations.

- Selected public educational projects on the desirability of and need for health maintenance examinations.

- Evaluation of effectiveness of public educational activities.

- Tumor registers collecting data of exceptional value.

- Extension and evaluation of rehabilitation programs (in cooperation with State rehabilitation agencies).
- Selected projects demonstrating effective treatment for cancer in public beneficiaries of medical care.

The types of projects suggested are not meant to exhaust all possibilities. Other worthwhile locally sponsored and locally directed demonstration projects will be considered on their own merits.

Applications are accepted from nonprofit organizations and institutions and official health agencies. The appropriate State health officer and Public Health Service regional medical director first review and process applications. The requests are then submitted to the advisory committee and the advisory council for recommendation of approval or disapproval. Formal action on applications and recommendations is taken by the chief of the Bureau of State Services, Public Health Service, to whom authority has been delegated by the Surgeon General.

Projects may be approved initially for as long as 3 years. When activities proceed satisfactorily and funds are available, assistance continues through the approved period. In special instances, assistance may include the assignment of personnel and the provision of equipment and supplies. Additional information and application forms may be obtained from the eight regional offices of the Public Health Service.

The Cancer Control Branch and its Advisory Committee believe that much can be done to reduce illness and death from cancer now, especially from cervical cancer. 